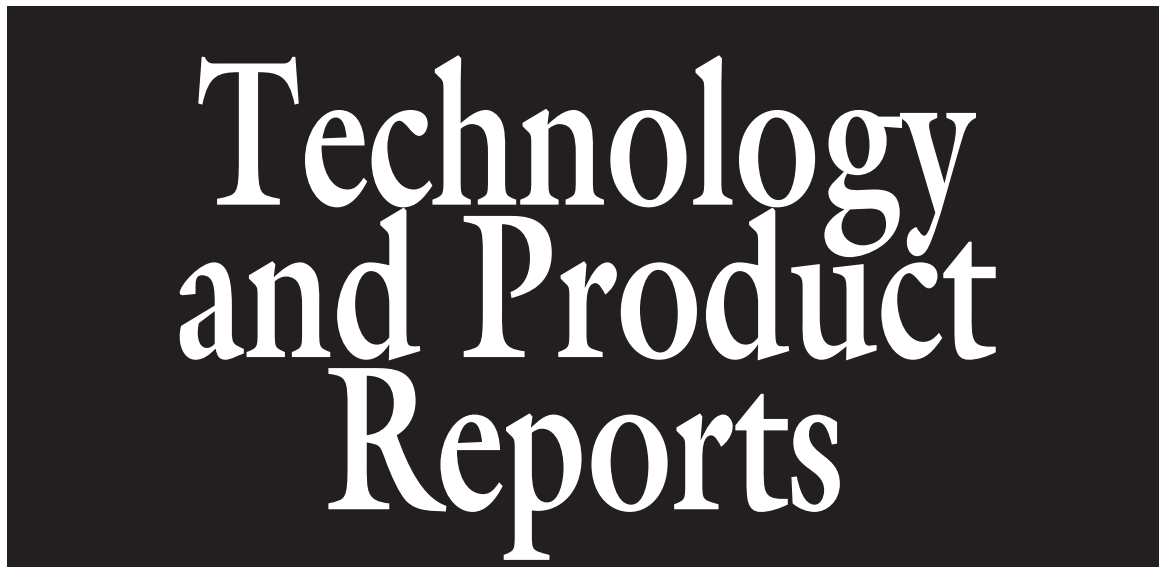

\section{A Comparison of Rapid Potentiometric and Colorimetric Methods for Measuring Tissue Nitrate Concentrations in Leafy Green Vegetables}

\section{Kristy A. Ott-Borrelli ${ }^{1,3}$, Richard T. Koenig ${ }^{1}$, and Carol A. Miles ${ }^{2}$}

Additional Index words. Cardy $\mathrm{NO}_{3}-\mathrm{N}$ meter, ion, selective electrode, ISE, fresh sap, dry tissue

Summary. Leafy green vegetables such as lettuce (Lactuca sativa), Asian greens (Brassica spp.) and spinach (Spinacia olevacea) have a tendency to accumulate high concentrations of potentially harmful nitrate-nitrogen $\left(\mathrm{NO}_{3}-\mathrm{N}\right)$. It would be advantageous for growers to have rapid and inexpensive methods to accurately measure plant tissue $\mathrm{NO}_{3}-\mathrm{N}$ to make fertility and harvest management decisions for these crops. This study compared fresh sap expressed from whole leaves and analyzed with a Cardy meter with the analysis of dry leaf tissue extracts analyzed with a benchtop ion selective electrode (ISE) and an automated colorimetric method for determining $\mathrm{NO}_{3}-\mathrm{N}$ concentration. Results from ISE and colorimetric analysis of the same dry leaf tissue extracts had a strong relationship $\left(r^{2}=0.92\right)$. The ISE was relatively easy to operate and affordable, suggesting it is an adequate substitute for automated colorimetric analysis of dry plant tissue extracts. Results of fresh whole leaf sap analyzed with the Cardy meter showed a poor relationship with dry leaf tissue extracted and analyzed using the ISE $\left(r^{2}=0.25\right)$ or with colorimetric analysis $\left(r^{2}=0.21\right)$. When fresh whole leaf sap was diluted $1: 1$ with aluminum sulfate $\left[\mathrm{Al}_{2}\left(\mathrm{SO}_{4}\right)_{3}\right]$ to adjust for potential matrix effects, there was still a relatively poor relationship $\left(r^{2}=0.41\right)$ between the diluted sap samples analyzed with a Cardy meter and the dry leaf tissue extracted and analyzed with the ISE. When the same dry leaf tissue extracts were analyzed with the Cardy meter and the ISE, the results related well $\left(r^{2}=0.96\right)$. As a result of tissue processing and/or instrument differences, Cardy meter analysis of sap expressed from whole leaves was not comparable to ISE or colorimetric analyses of dry leaf tissue extracts for leafy green vegetables.

$\mathrm{L}$ eafy green vegetables can accumulate high concentrations of nitrate-nitrogen $\left(\mathrm{NO}_{3}-\mathrm{N}\right)$ that are potentially harmful if consumed by humans (Blom-Zandstra, 1989; Corre and Breimer, 1979; Maynard et al., 1976; Roorda van Eysinga, 1984). Nitrate- $\mathrm{N}$ concentration in leafy greens can fluctuate diurnally because it is often inversely related to light intensity (Muramoto, 1999;
Reinink, 1991; Steingrover et al., 1986; Steingrover and Ratering, 1986). As a result of rapid $\mathrm{NO}_{3}-\mathrm{N}$ fluctuation, it would be convenient for growers to be able to quickly monitor concentrations to optimize fertilization and harvest timing. $\mathrm{Al}$ though conventional means of measuring plant tissue $\mathrm{NO}_{3}-\mathrm{N}$ are accurate, well accepted, and reliable, they often require sophisticated equipment and trained technicians and can be timeconsuming, expensive, and impractical outside of a laboratory setting.

Many laboratories are interested in analytical methodology capable of overcoming the inconveniences and high costs of conventional methods such as sequential or flow injection analysis (Lin et al., 2005). Potentiometric methods involve the use of ion selective electrodes (ISEs) to measure ion concentrations in plant tissue and soil extracts and are relatively inexpensive, easy to operate, and rapid (Watson and Isaac, 1990). These advantages of potentiometry have led to the development of $\mathrm{NO}_{3}-\mathrm{N}$ ISEs that expedite analytical procedures (Lin et al., 2005). An Orion 93$07 \mathrm{NO}_{3}-\mathrm{N}$ ion-selective electrode and Orion 90-02 double-junction reference electrode (Thermo Fisher Scientific, Waltham, MA) gave accurate and precise $\mathrm{NO}_{3}-\mathrm{N}$ measurements of vegetable tissue extracts (Consalter et al., 1992) and in situ measurements of soil $\mathrm{NO}_{3}-\mathrm{N}$ concentration (Thottan et al., 1994). Lin et al. (2005) analyzed solutions of mineral water and vegetable extracts with two ISEs and a spectrophotometric method and found that the potentiometric methods were both precise and accurate with no significant difference between the two methods at the $95 \%$ confidence level.

Relatively inexpensive and portable ISE nutrient monitoring devices such as the Cardy $\mathrm{NO}_{3}-\mathrm{N}$ meter (Horiba Insruments, Irvine, CA, and Spectrum Technologies, Plainfield, IL) are capable of measuring fresh plant sap $\mathrm{NO}_{3}-\mathrm{N}$ levels directly. Several authors have shown that measurements made with the Cardy meter using nondiluted plant sap were well correlated to conventional methods

\begin{tabular}{llll}
\hline $\begin{array}{l}\text { Units } \\
\begin{array}{l}\text { To convert U.S. to SI, } \\
\text { multiply by }\end{array}\end{array}$ & U.S. unit & SI unit & $\begin{array}{l}\text { To convert SI to U.S., } \\
\text { multiply by }\end{array}$ \\
\hline 29.5735 & $\mathrm{fl} \mathrm{oz}$ & $\mathrm{mL}$ & 0.0338 \\
28.3495 & $\mathrm{Oz}$ & $\mathrm{g}$ & 0.0353 \\
1 & $\mathrm{Ppm}$ & $\mathrm{mg} \cdot \mathrm{kg}^{-1}$ & 1 \\
1 & $\mathrm{Ppm}$ & $\mathrm{mg} \cdot \mathrm{L}^{-1}$ & 1 \\
$\left({ }^{\circ} \mathrm{F}-32\right) \div 1.8$ & ${ }^{\circ} \mathrm{F}$ & ${ }^{\circ} \mathrm{C}$ & $\left(1.8 \times{ }^{\circ} \mathrm{C}\right)+32$
\end{tabular}


of $\mathrm{NO}_{3}-\mathrm{N}$ analysis (Altland et al., 2002, 2003; Hartz et al., 1993; Westcott et al., 1998). However, others found Cardy meter $\mathrm{NO}_{3}-\mathrm{N}$ values were consistently higher than values derived from conventional analysis methods unless sap was diluted to account for ionic strength effects and specific ion interferences (Davenport and Jabro, 2001; Errebhi et al., 1998; Hochmuth, 1994; Kubota et al., 1996; Rosen et al., 1996; Westcott et al., 1993). Although several of these authors suggest that dilution may be necessary to improve accuracy, most still found adequate relationships between conventional methods of tissue analysis and fresh sap analysis with the Cardy meter (Errebhi et al., 1998; Kubota et al., 1996; Rosen et al., 1996; Westcott et al., 1993, 1998).

The objective of this study was to compare the analysis of fresh leaf sap using a Cardy portable $\mathrm{NO}_{3}$ meter with dry leaf tissue extracts analyzed using ISE and colorimetric methods to determine if rapid, less expensive tissue processing and analysis methods can substitute for more laborious procedures requiring expensive instrumentation for quality assessment in leafy green vegetables.

\section{Materials and methods}

Samples for this study were taken from a larger experiment in which 24 varieties of lettuce, Asian greens, and spinach were harvested three times at two locations during winter (Ott, 2007). Comparisons between methods of analysis described subsequently used different subsample groups of plants taken from this larger experiment. Because the purpose of this study was to compare methods of

This paper is a portion of a Master's thesis submitted by Kristy A. Ott-Borrelli at Washington State University.

We are grateful for funding provided by Washington State University's Center for Sustaining Agriculture and Natural Resources (CSANR), Biologically Intensive and Organic Agriculture (BIOAg) program, and the Glen D. Franklin Endowed Graduate Fellowship in the Department of Crop and Soil Sciences.

Use of trade names does not imply endorsement of the products named or criticism of similar ones not named.

${ }^{1}$ Department of Crop and Soil Sciences, Washington State University, P.O. Box 646420, Pullman, WA 99164-6420

${ }^{2}$ Department of Horticulture and Landscape Architecture, Washington State University, Northwestern Research and Extension Center, Mount Vernon, WA 98273-4768

${ }^{3}$ Corresponding author. E-mail: kristy_ott@wsu.edu. tissue processing and analysis, the effects of location, growing conditions, and variety on tissue $\mathrm{NO}_{3}-\mathrm{N}$ concentration are not discussed here.

After harvest, all fresh plant samples were rinsed with distilled water to remove soil and other debris from the leaves. Two to four outermost leaves, including petioles, from lettuce, Asian greens, and spinach were selected for processing and $\mathrm{NO}_{3}-\mathrm{N}$ analyses as described subsequently. Because the objective of this study involved quality assessment of leafy green vegetables for human consumption, whole leaves were used in the analyses instead of petiole tissue, which would have been more relevant for fertility analyses in these crops. Leaf samples intended for dry tissue extraction and analysis were weighed before and after drying for $48 \mathrm{~h}$ at $80^{\circ} \mathrm{C}$. Leaf samples intended for fresh sap analysis were processed immediately after rinsing.

DRY LEAF TISSUE PROCESSING. Oven-dry leaf samples were ground with a mortar and pestle and placed in plastic vials for storage. For dry extraction, $0.4 \mathrm{~g}$ of tissue was transferred to a $50-\mathrm{mL}$ vial to which $40 \mathrm{~mL}$ of $0.025 \mathrm{M} \mathrm{Al}_{2}\left(\mathrm{SO}_{4}\right)_{3}$ extracting solution was added (Baker and Smith, 1969; Heanes, 1982). If the sample did not have $0.4 \mathrm{~g}$ of tissue, the maximum amount available was weighed and the weight was recorded. The vial was capped and shaken for $30 \mathrm{~min}$. The solution was filtered through a Whatman \#42 filter paper into clean vials and refrigerated (Heanes, 1982).

ION SELECTIVE ELECTRODE ANALYSIs. All dry leaf tissue extracts $(\mathrm{n}=544)$ were analyzed using an Orion 720A+ meter coupled with an Orion Ionplus $\mathrm{NO}_{3}$ ISE (Thermo Fisher Scientific). The ISE was calibrated using $\mathrm{NO}_{3}-\mathrm{N}$ standards at concentrations of $1.4,14$, and 140 $\mathrm{mg} \cdot \mathrm{L}^{-1}$ prepared using a $0.1 \mathrm{M} \mathrm{NO}_{3}$ stock solution (Thermo Fisher Scientific) in a $0.025 \mathrm{M} \mathrm{Al}_{2}\left(\mathrm{SO}_{4}\right)_{3}$ matrix. Each analyte was brought to room temperature before analysis. Approximately $30 \mathrm{~mL}$ of solution was poured into a $50-\mathrm{mL}$ beaker and stirred using a magnetic bar and stir plate. The ISE was placed directly into the solution and a reading recorded after the meter stabilized. The ISE was checked for drift by reading the 14 $\mathrm{mg} \cdot \mathrm{L}^{-1} \quad \mathrm{NO}_{3}-\mathrm{N}$ standard every six samples. If the value deviated from the standard by greater than $10 \%$, the meter was recalibrated.

Colorimetric analysis. A subset $(n=183)$ of dried leaf tissue extracts prepared for ISE analysis was selected for colorimetric analysis using a continuous flow auto analyzer (Quick Chem FIA+ 8000 Series; Lachat Instruments, Milwaukee, WI). This instrument uses a cadmium column to reduce $\mathrm{NO}_{3}$ to nitrite $\left(\mathrm{NO}_{2}\right)$ followed by analysis of the $\mathrm{NO}_{2}$ using the modified Griess-Ilosvay method at a wavelength of $540 \mathrm{~nm}$ (Mulvaney, 1996). Extract samples were diluted before analysis to obtain concentrations within the standard curve of the instrument.

Fresh LEAF TISSUE PROCESSING AND ANALYsIs. A Cardy $\mathrm{NO}_{3}$ meter (Horiba Instruments and Spectrum Technologies) was used to analyze samples of fresh and diluted leaf sap and a subset of dry plant tissue extract samples prepared as described previously for ISE analysis. Direct analysis of fresh sap with the Cardy meter was performed on selected plants $(\mathrm{n}=$ 352) that were also processed for dry plant tissue extracts and analyzed with the ISE and/or colorimetric procedures. From each plant, two outermost leaves, including petioles, were placed into a fresh tissue press. The intent was to express two samples $(\approx 0.5 \mathrm{~mL}$ each $)$ of fresh sap directly onto the Cardy meter electrode and to average the two readings. Frequently, delicate plant tissue would pass through the press and sufficient sap could be obtained for only one reading.

Personnel operated separate meters according to instructions described in the operation manual (Spectrum Technologies, 1997). The Cardy meter was calibrated with $\mathrm{NO}_{3}-\mathrm{N}$ standards of 20 and 450 $\mathrm{mg} \cdot \mathrm{L}^{-1}$ in a deionized water matrix, provided by the manufacturer, and recalibrated every three to five samples to prevent drift. The manual recommends taking a reading after 30 to $45 \mathrm{~s}$. However, the meter did not stabilize for $\approx 2$ to $5 \mathrm{~min}$, which is when measurements were recorded. The sensor was replaced after $\approx 200$ samples or as necessary when the meter failed to calibrate.

Selected samples $(n=50)$ of the dry leaf tissue extract prepared for ISE and colorimetric analysis were also analyzed with the Cardy meter. The 
Cardy meter was calibrated with two of the three ISE $\mathrm{NO}_{3}-\mathrm{N}$ standards: 14 and $140 \mathrm{mg} \cdot \mathrm{L}^{-1}$ in the $0.025 \mathrm{M}$ $\mathrm{Al}_{2}\left(\mathrm{SO}_{4}\right)_{3}$ matrix. In addition, fresh sap samples $(\mathrm{n}=25)$ were diluted with $\mathrm{Al}_{2}\left(\mathrm{SO}_{4}\right)_{3}$ and analyzed for $\mathrm{NO}_{3}-\mathrm{N}$ concentration with the Cardy meter to compare with dry tissue extracts of the same plants analyzed with the ISE. Diluted samples were prepared by placing two leaves into a fresh tissue press and expressing sap into a weigh boat. Fresh sap $(0.5 \mathrm{~mL})$ was transferred by pipette and mixed with $0.5 \mathrm{~mL}$ of $0.025 \mathrm{M} \mathrm{Al}_{2}\left(\mathrm{SO}_{4}\right)_{3}$ in a separate weigh boat. Two separate samples $(0.5 \mathrm{~mL}$ each $)$ of the diluted solution were transferred to the electrode of the Cardy meter and results averaged. The average dilute sap value was multiplied by two to account for the dilution factor.

Calculations. Nitrate-N readings derived from the ISE and colorimetric analyses of dry leaf tissue extracts were adjusted using the relative water content (RWC) of the subsamples to the same units as the Cardy meter (milligrams per liter of sap) for direct comparison. Fresh tissue $\mathrm{NO}_{3}-\mathrm{N}$ concentrations were calculated by multiplying the $\mathrm{NO}_{3}-\mathrm{N}$ concentration in the dry tissue extract by the ratio of the volume of $\mathrm{Al}_{2}\left(\mathrm{SO}_{4}\right)_{3}$ solution per kilogram of ground tissue used in the extraction process and then dividing by the RWC of each plant sample (liters per kilogram of dry tissue).

STATistics. Simple linear regression analysis was conducted using Sigma Plot ${ }^{\mathrm{TM}}$ software (Systat Software, San Jose, CA) to estimate the coefficient of determination $\left(r^{2}\right)$, yintercept, and slope of the regression line. Confidence intervals for slope and $y$-intercept parameters in the regression equations were calculated from sEs obtained in regression analyses (Statistix 7.0; Analytical Software, Tallahassee, FL) and t-values obtained from an online calculator (National Institute of Standards and Technology, 2006). Confidence intervals were used to determine if values for the slope were different from one and $y$-intercept different from zero.

\section{Results and discussion}

COLORIMETRIC AND ION SELECTIVE ELECTRODE ANALYSIS. There was strong relationship between colorimetric and ISE analyses of the same dry tissue extracts $\left[r^{2}=0.92\right.$ (Fig. 1)]. However, concentrations determined using the ISE were consistently higher than for colorimetric analysis. The slope and $y$-intercept of the regression line between the two methods were significantly higher than 1 and 0 , respectively (Fig. 1). Deviation of the slope from 1 could be attributable in part to nine samples with $\mathrm{NO}_{3}-\mathrm{N}$ concentrations above the highest calibration standard for the ISE (140 $\left.\mathrm{mg} \cdot \mathrm{L}^{-1}\right)$. Readings obtained beyond these points may not be as accurate as those that fall within the calibration range if the calibration is not linear beyond the range of the standards. Removing values greater than $140 \mathrm{mg} \cdot \mathrm{L}^{-1}$ only slightly altered the regression analysis $\left(r^{2}=0.94, \mathrm{y}=1.20 \mathrm{x}+4.45\right)$, indicating that $\mathrm{NO}_{3}-\mathrm{N}$ values above the calibration range were not responsible for differences between the analytical methods. The higher ISE $\mathrm{NO}_{3}-\mathrm{N}$ concentrations could be caused by the calibration standards themselves. When the ISE standards were analyzed using the colorimetric method, the $\mathrm{NO}_{3}-\mathrm{N}$ concentrations were $1.5,12.9$, and $125 \mathrm{mg} \cdot \mathrm{L}^{-1} \mathrm{com}-$ pared with prepared concentrations of $1.4,14$, and $140 \mathrm{mg} \cdot \mathrm{L}^{-1}$, respectively. The lower colorimetric assay concentrations of the ISE standards would result in ISE values that were higher than the colorimetric values and would explain the results in Figure 1. An alternative explanation is that the standards against which the colorimetric instrument is calibrated are not accurate. Standards for both ISE and colorimetric instruments are prepared from stock solutions and are subject to dilution and other errors during preparation. Although values from the ISE were higher than those returned by the colorimetric procedure, the relative simplicity and low cost of the ISE, coupled with the high coefficient of determination between the ISE and colorimetric methods, suggests that the ISE could be an adequate substitute for automated colorimetric methods of dry leaf tissue extract analysis for $\mathrm{NO}_{3}-\mathrm{N}$. Paul and Carlson (1968) found that results from a $\mathrm{NO}_{3}-\mathrm{N}$ ion-specific electrode were similar with those obtained by the phenoldisulfonic acid colorimetric method, and Consalter et al. (1992) found that an Orion 93-07 $\mathrm{NO}_{3}-\mathrm{N}$ ISE coupled with an Orion 90-02 double junction reference electrode

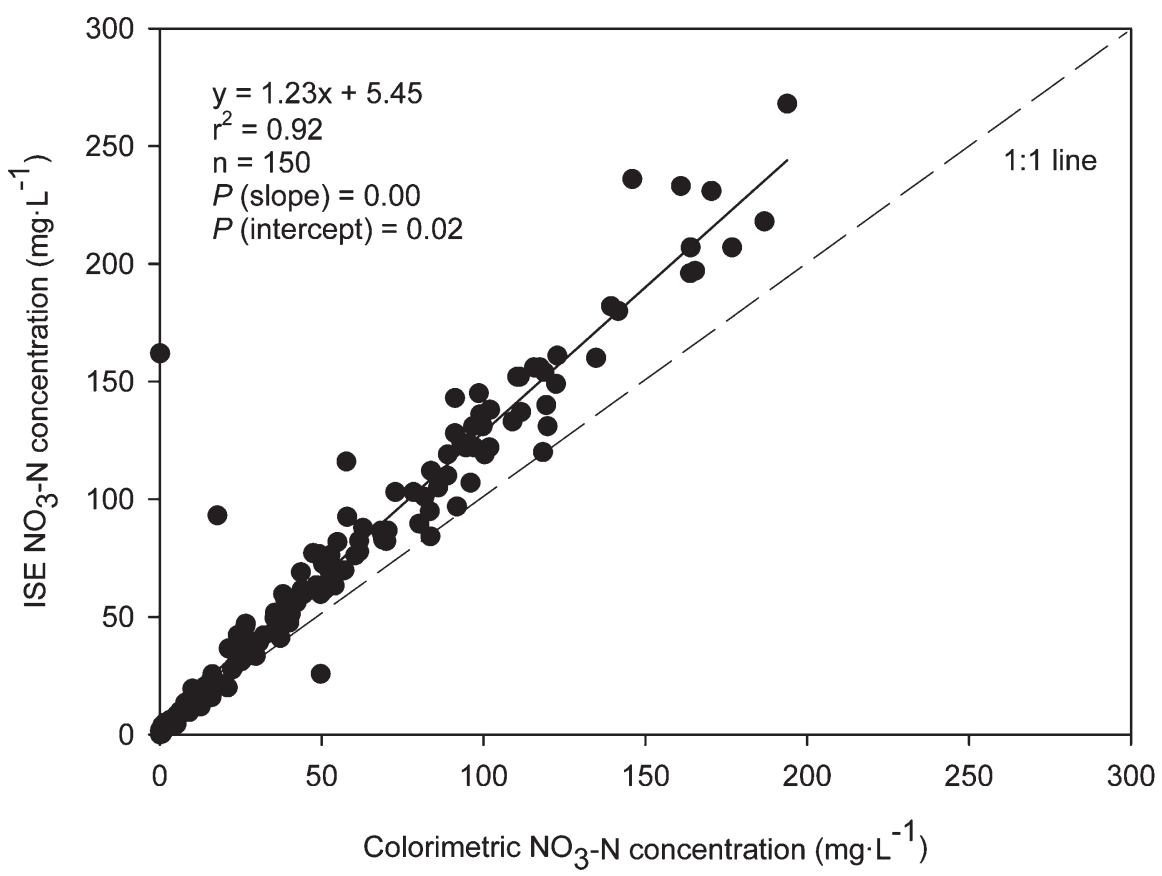

Fig. 1. Comparison of leafy green vegetable (lettuce, Asian greens, and spinach) nitrate-nitrogen $\left(\mathrm{NO}_{3}-\mathrm{N}\right)$ concentrations from dry whole leaf tissue extracts using colorimetric analysis and an ion selective electrode (ISE). The 95\% confidence intervals for regression line parameters are: 1.17 to 1.29 for the slope and 1.15 to 9.75 for the $y$-intercept $\left(1 \mathrm{mg} \cdot \mathrm{L}^{-1}=1 \mathrm{ppm}\right)$. 
accurately recovered $\mathrm{NO}_{3}-\mathrm{N}$ from a variety of vegetable species.

CARDY METER COMPARISONS. There was a poor relationship between fresh leaf sap $\mathrm{NO}_{3}-\mathrm{N}$ concentration determined with a Cardy meter and dry leaf tissue extracts analyzed with either the ISE $\left[r^{2}=0.25\right.$ (Fig. 2)] or the colorimetric $\left[r^{2}=0.21\right.$ (Fig. 2)] procedures and expressed on a sap concentration (milligrams per liter) basis. Analysis of fresh leaf sap with the Cardy meter produced values that were consistently higher than dry tissue extracts of the same plants orimetric procedures.

Results of this study suggest that the extraction and analysis of fresh leaf sap with a Cardy meter is not comparable to procedures in which dry leaf tissue is extracted and analyzed with ISE or colorimetric procedures to determine $\mathrm{NO}_{3}-\mathrm{N}$ concentrations. Other authors found that analysis of fresh plant sap with a Cardy meter produced values that were consistently higher than more standard analytical methods (Davenport and Jabro, 2001; Errebhi et al., 1998; Rosen et al., 1996; Westcott et al., 1993). For analyzed with either the ISE or col-

example, Errebhi et al. (1998) found that potato (Solanum tuberosum) sap $\mathrm{NO}_{3}-\mathrm{N}$ concentrations from a Cardy meter were an average of $50 \mathrm{mg} \cdot \mathrm{L}^{-1}$ higher than sap concentrations measured with another instrument. However, these authors noted that the Cardy meter was a quick and useful tool with strong precision $\left(r^{2}=0.91\right)$ when comparing fresh plant sap with dry tissue $\mathrm{NO}_{3}$ concentrations. Davenport and Jabro (2001) found that the Cardy meter produced values 10 to 1000 times higher than conventional analysis when soil slurry samples were analyzed for $\mathrm{NO}_{3}-\mathrm{N}$ and concluded that the Cardy meter is not a suitable tool for analyzing soil slurries.

Several authors found that Cardy meter analysis of fresh plant sap was well correlated with several methods of dry tissue extract and analysis for $\mathrm{NO}_{3}-\mathrm{N}$ and suggested the Cardy could provide rapid, precise $\mathrm{NO}_{3}-\mathrm{N}$ measurements for a variety of crops (Altland et al., 2002, 2003; Hartz et al., 1993; Kubota et al., 1996; Rosen et al., 1996; Westcott et al., 1993, 1998). Authors note that it may be necessary to dilute samples that are

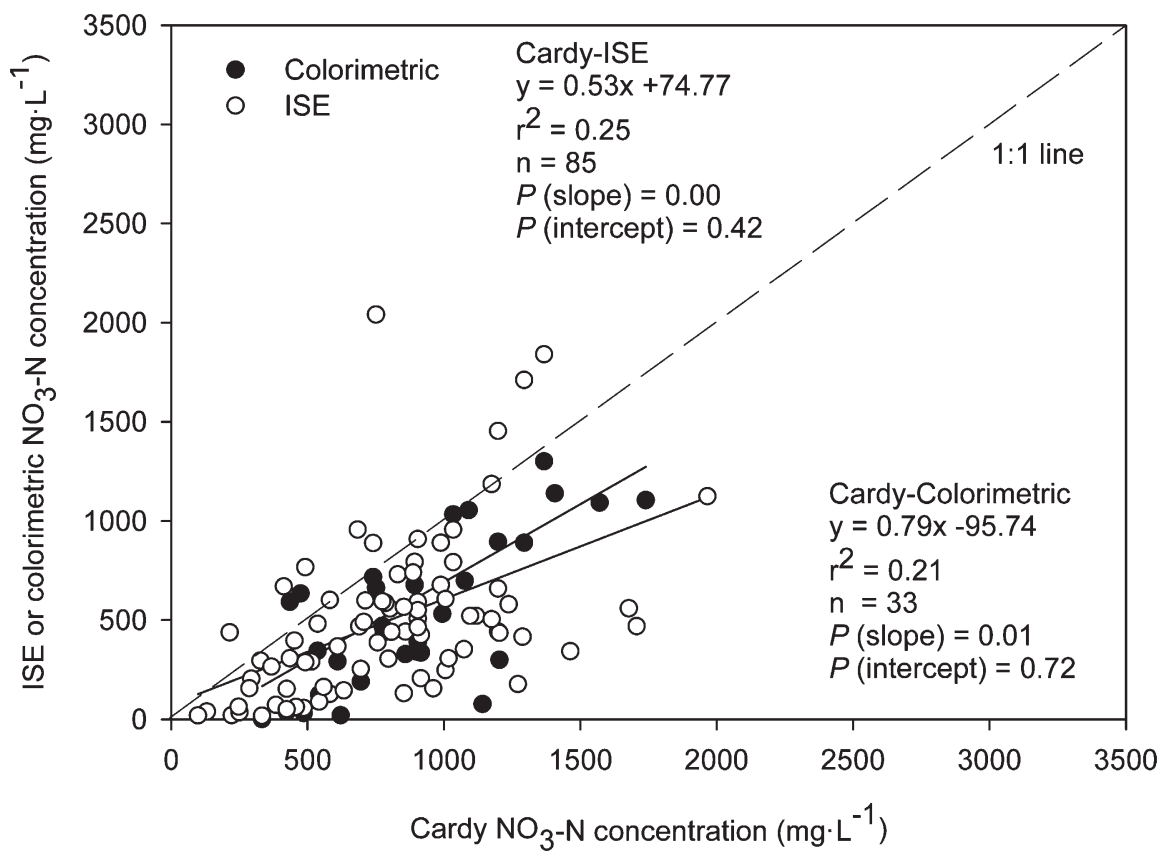

Fig. 2. Comparison of leafy green vegetable (lettuce, Asian greens, and spinach) nitrate-nitrogen $\left(\mathrm{NO}_{3}-\mathrm{N}\right)$ concentrations from dry whole leaf tissue extracts using colorimetric analysis and an ion selective electrode (ISE) with analysis of whole leaf fresh sap using a Cardy meter. The $\mathbf{9 5 \%}$ confidence intervals for the regression line parameters of the Cardy meter versus colorimetric comparison are: 0.25 to 1.33 for the slope and -621 to 430 for the $y$-intercept. The regression line parameters of the Cardy meter versus ISE comparison are: 0.33 to 0.73 for the slope and-104 to 253 for the $\mathrm{y}$-intercept $\left(1 \mathrm{mg} \cdot \mathrm{L}^{-1}=1 \mathrm{ppm}\right)$. beyond the calibration range of the meter (Hochmuth, 1994; Rosen et al., 1996; Westcott et al., 1993), although Rosen et al. (1996) found a linear relationship between methods of analysis up to $2000 \mathrm{mg} \cdot \mathrm{L}^{-1} \mathrm{NO}_{3^{-}}$ $\mathrm{N}$, suggesting that the linear range of the Cardy meter extends well beyond the high standard concentration. In the present study, the majority of fresh plant sap samples had $\mathrm{NO}_{3}-\mathrm{N}$ concentrations above the high standard of $450 \mathrm{mg} \cdot \mathrm{L}^{-1}$. However, relationships between fresh sap analyzed with the Cardy meter and dry tissue extracts analyzed with the ISE or colorimetric procedures were poor at sap concentrations $450 \mathrm{mg} \cdot \mathrm{L}^{-1} \mathrm{NO}_{3^{-}}$ $\mathrm{N}$ or less (Fig. 2).

It is possible that we introduced errors when the dry leaf tissue extract values from the ISE and colorimetric analyses were adjusted arithmetically to fresh sap concentrations using the moisture content determined for each individual sample. Vitosh and Silva (1994) found a highly significant linear correlation between fresh plant sap and dry plant tissue $\mathrm{NO}_{3}-\mathrm{N}$ concentrations using a portable $\mathrm{HACH}$ One $\mathrm{pH} / \mathrm{ISE}$ meter (Hach, Loveland, $\mathrm{CO}$ ). Other researchers found adequate relationship between nondiluted plant sap analyzed with a Cardy meter and petiole $\mathrm{NO}_{3}-\mathrm{N}$ expressed on a dry weight basis (Altland et al., 2002, 2003; Errebhi et al., 1998; Hartz et al., 1993, Hochmuth, 1994; Kubota et al., 1996; Westcott et al., 1993, 1998). To determine whether errors in tissue water content determination affected the comparisons in this study, fresh sap $\mathrm{NO}_{3}-\mathrm{N}$ concentrations (milligrams per liter of sap) determined from the Cardy meter were compared with dry plant extract $\mathrm{NO}_{3}-\mathrm{N}$ concentrations (milligrams per kilogram of dry tissue) determined with the ISE for data in Figure $2\left(r^{2}=0.30, \mathrm{y}=5.29 \mathrm{x}+1612\right)$. The poor relationship indicates that the problem between the two methods likely lies with tissue extraction and/ or analysis and not with the mathematical conversion of dry tissue to fresh sap concentrations.

Previous studies used similar plant materials when comparing the Cardy meter with other methods (Errebhi et al., 1998; Hartz et al., 1993; Kubota et al., 1996; Rosen et al., 1996; Vitosh and Silva, 1994; Westcott et al., 1993). The use of 
different plant tissue sampling methods (sap expressed from whole leaves versus whole leaf dry extract) is a possible source of error in this study. Nitrate- $\mathrm{N}$ concentration is higher in the petioles of leafy greens than in the leaf blades (Barker et al., 1974; Breimer, 1982; Maynard et al., 1976; Muramoto, 1999; Olday et al., 1976). Although we sampled the whole leaf in both fresh sap and dry tissue procedures, the majority of fresh sap likely came from the petiole because this tissue was more succulent than the leaf blade. Drying and processing the whole leaf may result in more dilute $\mathrm{NO}_{3}-\mathrm{N}$ concentrations compared with the analysis of sap expressed from fresh leaf samples.

When a subset of fresh leaf sap samples was diluted with $\mathrm{Al}_{2}\left(\mathrm{SO}_{4}\right)_{3}$ and analyzed with the Cardy meter, there was still a relatively poor relationship with dry plant tissue extracts analyzed with the ISE $\left(r^{2}=\right.$ 0.41 ), and slope and y-intercept values differed significantly from 1 and 0 , respectively (Fig. 3). This suggests that dilution of sap with an ionic strength adjuster before analysis with the Cardy meter was either not responsible for the poor relationship between methods or that a $1: 1$ dilution is not sufficient to account for ionic strength interferences. A comparison of dry tissue extract $\mathrm{NO}_{3}-\mathrm{N}$ (y-axis) to fresh plant sap $\mathrm{NO}_{3}-\mathrm{N}(\mathrm{x}-$ axis) showed an $\mathrm{x}$-intercept value of $322 \mathrm{mg} \cdot \mathrm{L}^{-1}$, indicating that at low or zero values of plant dry matter $\mathrm{NO}_{3}{ }^{-}$ $\mathrm{N}$, the Cardy meter was still indicating the presence of $\mathrm{NO}_{3}-\mathrm{N}$ (Westcott et al., 1993). These authors attribute the high $\mathrm{NO}_{3}-\mathrm{N}$ values of the Cardy meter to anion interferences and suggest that the addition of $\mathrm{Al}_{2}\left(\mathrm{SO}_{4}\right)_{3}$ is necessary to suppress these interferences. Kubota et al. (1996) also attribute differing results between dry petiole and petiole sap $\mathrm{NO}_{3}-\mathrm{N}$ measurement methods to ion interference in the absence of $\mathrm{Al}_{2}\left(\mathrm{SO}_{4}\right)_{3}$ in fresh sap analyses.

There was a strong relationship between instruments when the same dry plant tissue extracts were analyzed with the Cardy meter and ISE $\left[r^{2}=\right.$ 0.96 (Fig. 4)]. The slope and $\mathrm{y}^{-}$ intercept did not differ from 1 and 0 , respectively (Fig. 4). This strong relationship is attributed to the use of the same plant materials and extract procedures for this method. The

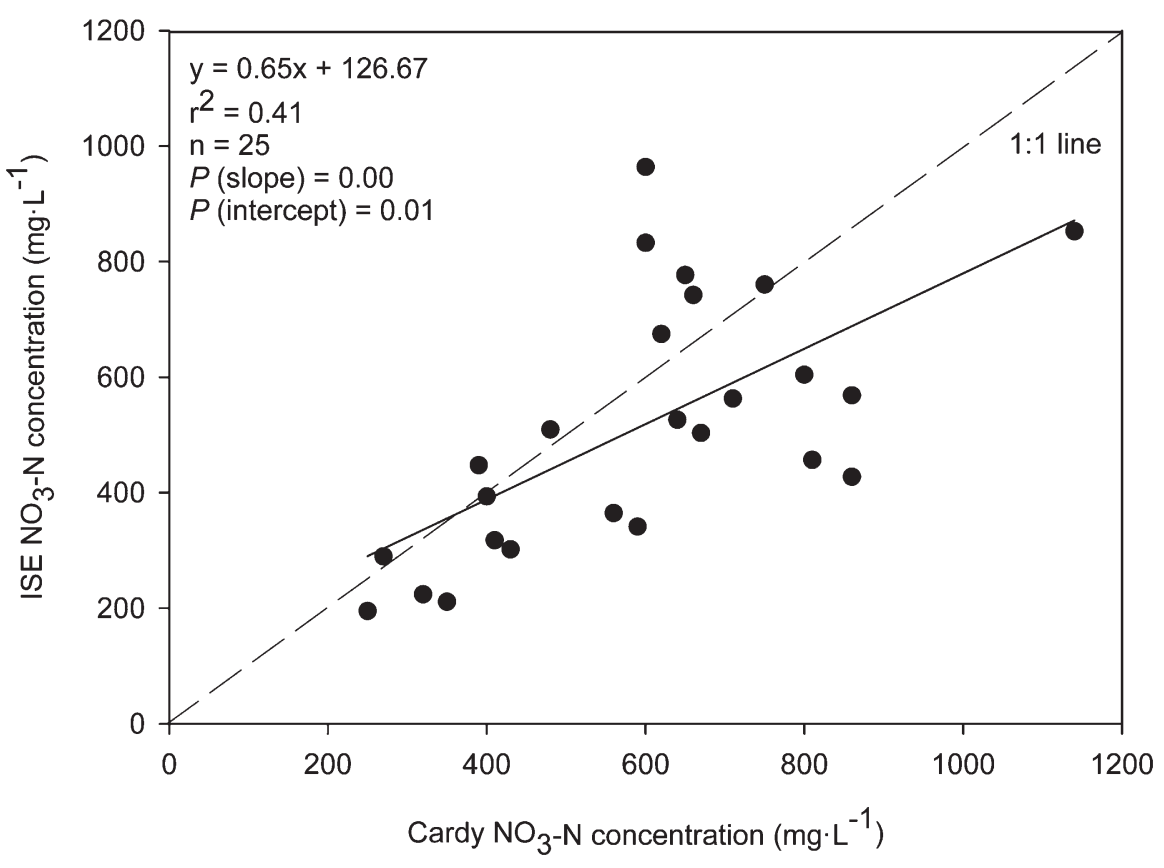

Fig. 3. Comparison of leafy green vegetable (lettuce, Asian greens, and spinach) nitrate-nitrogen $\left(\mathrm{NO}_{3}-\mathrm{N}\right)$ concentrations from dry whole leaf tissue extracts using an ion selective electrode (ISE) with rapid analysis of fresh plant sap diluted with $0.025 \mathrm{M}$ aluminum sulfate using a Cardy meter. The $95 \%$ confidence interval for regression line parameters are: 0.31 to 0.95 for the slope and 92 to 445 for the $y$ intercept $\left(1 \mathrm{mg} \cdot \mathrm{L}^{-1}=1 \mathrm{ppm}\right)$.

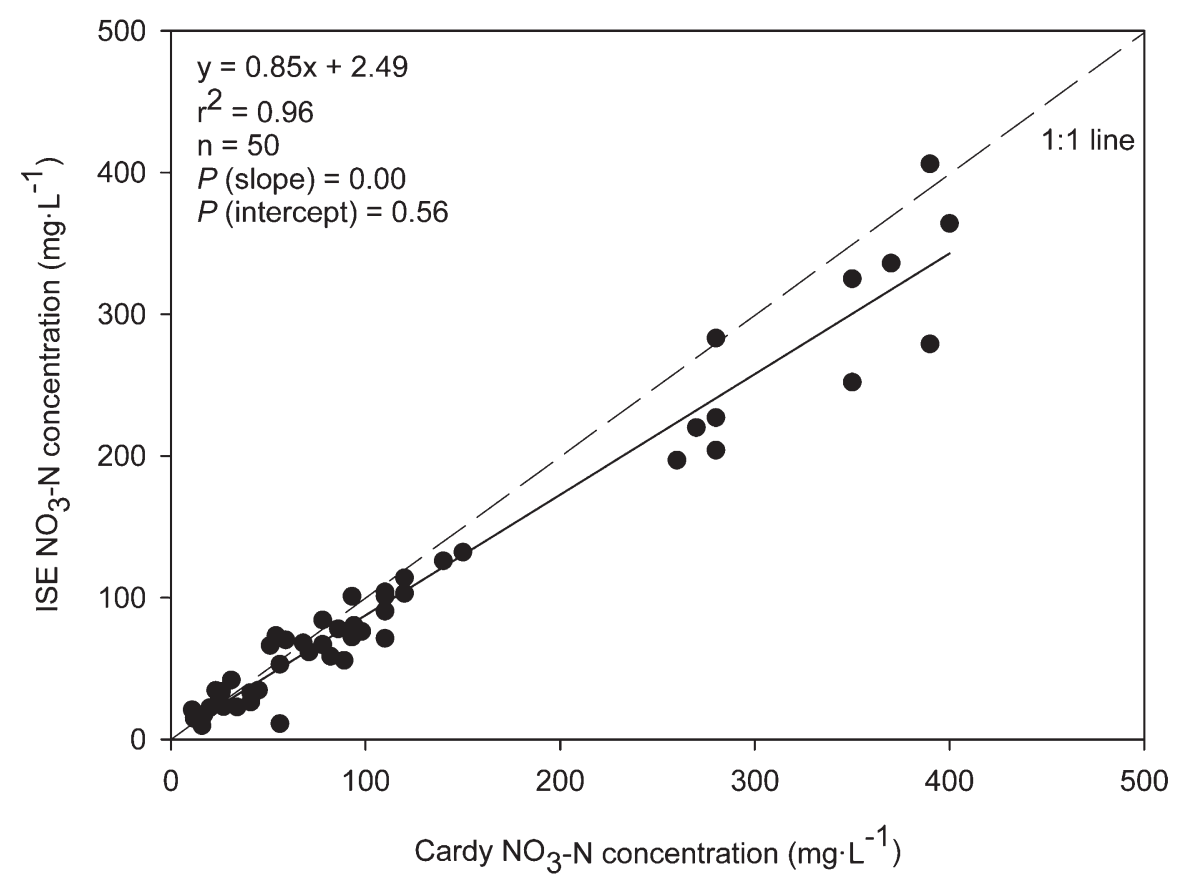

Fig. 4. Comparison of leafy green vegetable (lettuce, Asian greens, and spinach) nitrate-nitrogen $\left(\mathrm{NO}_{3}-\mathrm{N}\right)$ concentrations from dry whole leaf tissue extracts using an ion selective electrode (ISE) and a Cardy meter. The $95 \%$ confidence intervals for regression line parameters are: 0.34 to 1.36 for the slope and -6.27 to 11.25 for the $\mathrm{y}$-intercept $\left(1 \mathrm{mg} \cdot \mathrm{L}^{-1}=1 \mathrm{ppm}\right)$.

strong relationship between the Cardy meter and ISE analyses of the same dry plant tissue extracts suggests that the Cardy meter could substitute for ISE or colorimetric analysis of dry tissue extracted with $\mathrm{Al}_{2}\left(\mathrm{SO}_{4}\right)_{3}$. The drying, grinding, and extracting of dry plant tissues with $\mathrm{Al}_{2}\left(\mathrm{SO}_{4}\right)_{3}$ 
negates many of the purported benefits of the Cardy meter as a tool for rapid analysis of fresh plant sap and would not be feasible in a field setting for leafy green vegetables.

\section{Summary and conclusions}

Ion selective electrodes are accurate, easy to use, and less expensive than flow injection colorimetric instruments, making them an appealing substitute for analyzing large number samples for $\mathrm{NO}_{3}-\mathrm{N}$. However, in this study, rapid analysis of fresh leaf sap with a Cardy $\mathrm{NO}_{3}$ meter did not compare well to dry leaf tissue samples extracted and analyzed with an ISE or colorimetric procedure. Other researchers found that the Cardy meter can accurately measure $\mathrm{NO}_{3}-\mathrm{N}$ concentration in the tissue of other species, but it did not provide acceptable results for the leafy green vegetables included in this study. We were unable to determine if this was the result of a difference in tissue processing method (fresh leaf sap versus dry leaf tissue extract) or the analytical instruments used.

\section{Literature cited}

Altland, J.E., C.H. Gilliam, J.H. Edwards, G.J. Keever, D.C. Fare, and J.L. Sibley. 2002. Rapid determination of nitrogen status in annual Vinca. J. Environ. Hort. 20:189-194.

Altland, J.E., C.H. Gilliam, G.J. Keefer, J.H. Edwards, J.L. Sibley, and D.C. Fare. 2003. Rapid determination of nitrogen status in pansy. HortScience 38:537-541.

Baker, A.S. and R. Smith. 1969. Extracting solution for potentiometric determination of nitrate in plant tissue. J. Agr. Food Chem. 17:1284-1287.

Barker, A.V., D.N. Maynard, and H.A. Mills. 1974. Variations in nitrate accumulation among spinach cultivars. J. Amer. Soc. Hort. Sci. 99:132-134.

Blom-Zandstra, M. 1989. Nitrate accumulation in vegetables and its relationship to quality. Ann. Appl. Biol. 115:553-561.

Breimer, T. 1982. Environmental factors and cultural measures affecting the nitrate content in spinach. Fert. Res. 3:191-292.

Consalter, A., A. Rigato, L. Clamor, and P. Giandon. 1992. Determination of nitrate in vegetables using an ion-selected electrode. J. Food Composition Analysis $5: 252-256$.
Corre, W.J. and T.Breimer. 1979. Nitrate and nitrite in vegetables. Pudoc, Wageningen, The Netherlands.

Davenport, J.R. and J.D. Jabro. 2001. Assessment of hand held ion selective electrode technology for direct measurements of soil chemical properties. Commun. Soil Sci. Plant Anal. 32:30773085 .

Errebhi, M., C.J. Rosen, and D.E. Birong. 1998. Calibration of a petiole sap nitrate test for irrigated 'Russet Burbank' potato. Commun. Soil Sci. Plant Anal. 29:23-35.

Hartz, T.K., R.F. Smith, M. LeStrange, and K.F. Schulbach. 1993. On-farm monitoring of soil and crop nitrogen status by nitrate-selective electrode. Commun. Soil Sci. Plant Anal. 24:2607-2615.

Heanes, D.L. 1982. Determination of nitrate- $\mathrm{N}$ in plants by an improved extraction procedure adapted for ultraviolet spectrophotometry. Commun. Soil Sci. Plant Anal. 13:805-818.

Hochmuth, G.J. 1994. Efficiency ranges for nitrate-nitrogen and potassium for vegetable petiole sap quick tests. HortTechnology 4:218-222.

Kubota, A., T.L. Thompson, T.A. Doerge, and R.E. Godin. 1996. A petiole sap nitrate test for cauliflower. HortScience 31:934-937.

Lin, P.K.T., A.N. Araujo, M.C.B.S.M. Montenegro, and R. Pérez-Olmos. 2005. New PVC nitrate-selective electrode: Application to vegetables and mineral waters. J. Agr. Food Chem. 53:211215.

Maynard, D.N., A.V. Barker, P.L. Minotti, and N.H. Peck. 1976. Nitrate accumulation in vegetables. Adv. Agron. 28:71-118.

Mulvaney, R.L. 1996. Nitrogen-inorganic forms, p. 1123-1184 In: Sparks, D.L. (ed.). Methods of soil analysisPart 3. SSSA Book Ser. 5. Soil Sci. Soc. Amer./Amer. Soc. Agron., Madison, WI.

Muramoto, J. 1999. Comparison of nitrate content in leafy vegetables from organic and conventional farms in California. 15 July 2008. <http://www.agroecology.org/ documents/Joji/leafnitrate.pdf>.

National Institute of Standards and Technology. 2006. NIST/SEMATECH ehandbook of statistical methods. 5 Mar. 2008. <http://www.itl.nist.gov/div898/ handbook/>.

Olday, F.C., A.V. Barker, and D.N. Maynard. 1976. A physiological basis for different patterns of nitrate accumulation in two spinach cultivars. J. Amer. Soc. Hort. Sci. 101:217-219.
Ott, K.A. 2007. Impacts of winter growing conditions on yield and nitrate accumulation in organically produced leafy greens. MS thesis, Washington State Univ., Pullman, WA.

Paul, J.L. and R.M. Carlson. 1968. Nitrate determination in plant extracts by the nitrate electrode. J. Agr. Food Chem. 16:766-768.

Reinink, K. 1991. Genotype-environmental interaction for nitrate concentration in lettuce. Plant Breed. 107:39-49.

Roorda van Eysinga, J.P.N.L. 1984. Nitrate in vegetables under protected cultivation. Acta Hort. 145:251-256.

Rosen, C.J., M. Errebhi, and W. Wang. 1996. Testing petiole sap for nitrate and potassium: A comparison of several analytical procedures. HortScience 31:11731176.

Spectrum Technologies. 1997. Operation manual Cardy $\mathrm{NO}_{3}$-nitrate meter. Spectrum Technologies, Inc., Plainfield, IL.

Steingrover, E., P. Ratering, and J. Siesling. 1986. Daily changes in uptake reduction and storage of nitrate in spinach grown at low light intensity. Physiol. Plant. 66:550-556.

Steingrover, E. and P. Ratering. 1986. Effect of one night with 'low light' on uptake, reduction and storage of nitrate in spinach. Physiol. Plant. 66:557-562.

Thottan, J., J.F. Adsett, K.J. Sibley, and C.M. MacLeod. 1994. Laboratory evaluation of the ion selective electrode for use in an automated soil nitrate monitoring system. Commun. Soil Sci. Plant Anal. 25:3025-3034.

Vitosh, M.L. and G.H. Silva. 1994. A rapid petiole sap nitrate-nitrogen test for potatoes. Commun. Soil Sci. Plant Anal. 25:183-190.

Watson, M.E. and R.A. Isaac. 1990. Analytical instruments for soil and plant analysis, p. 691-740. In: Westerman, R.L. (ed.). Soil testing and plant analysis. 3rd Ed. SSSA Book Ser. 3. Soil Sci. Soc. Amer./Amer. Soc. Agron., Madison, WI.

Westcott, M.P., S.D. Cash, J.S. Jacobsen, G.R. Carlson, and L.E. Welty. 1998. Sap analysis for diagnosis of nitrate accumulation in cereal forages. Commun. Soil Sci. Plant Anal. 29:1355-1363.

Westcott, M.P., C.J. Rosen, and W.P. Inskeep. 1993. Direct measurement of petiole sap nitrate in potato to determine crop nitrogen status. J. Plant Nutr. 16:515-521. 